\title{
Hukum Masyarakat Nelayan Saka dalam Sistem Hukum Nasional
}

\author{
Sabian Utsman \\ Sekola Tinggi Agama Islam Negeri Palangka Raya \\ Jl. G. Obos X Palangka Raya \\ sabian_usman@yahoo.co.id
}

\begin{abstract}
This research discusses the problems as follows: First, how Saka fisherman community understands the mastery concept and the ownership of Saka $(\mathrm{Hp} 2 \mathrm{~S})$ that are socially constructed from generation to generation as the legal system existing in the traditional fisherman community in the Regency of Tumbang Nusa of Pulang Pisau, Central Kalimantan; second, how Saka fisherman community manages the conflicts; and third, what attempts can be performed in order that the legal norms of Saka fisherman community can be acknowledged in the legal system development process. This research uses the sociology of law study type with emic perspective. The research result concludes that: first, the mastery of Saka is temporary before the decision on acknowledgement as the owner is made. The process of Saka ownership is initiated from the invention of Saka which is not yet owned by anybody. Later, that Saka is confirmed as owned property and gets the acknowledgement from the community. Second, from generation to generation, they manage the conflicts using deliberation to reach consensus. The form of conflict management of Hp2S using "deliberation to reach consensus" is mostly dominated by men as the role models (the elders) in each group owning Saka. Third, the effort which can be done by the government is creating the new regulations of law or reconstructing the normative bases, or at least creating the regulations of the protection of Hp2S values in the national legal system.
\end{abstract}

Key words : Saka fisherman community, national legal system

\begin{abstract}
Abstrak
Penelitian ini mengangkat permasalahan: pertama, bagaimana sosok masyarakat nelayan Saka memahami konsep penguasaan Saka, dan pemilikan Saka (Hp2S) yang terkonstruksi (socially constructed) secara turun-temurun sebagai sistem hukum yang hidup di masyarakat nelayan tradisional di Tumbang Nusa Kabupaten Pulang Pisau Kalimantan Tengah? Kedua, bagaimana pengelolaan konflik (How to Manage Conflict) yang dilakukan masyarakat nelayan Saka. Ketiga, upaya-upaya yang dapat dilakukan agar norma-norma hukum masyarakat nelayan Saka mendapatkan pengakuan dalam proses pembangunan sistem hukum. Penelitian ini menggunakan tipe kajian sosiologi hukum dengan perspektif emik. Hasil penelitian menyimpulkan bahwa: pertama, penguasaan Saka adalah bersifat sementara sebelum mempunyai ketetapan menjadi pemilik. Proses pemilikan Saka dimulai dari penemuan Saka yang belum ada kepemilikan, kemudian Saka tersebut diakui sebagai hak milik dan akhirnya mendapat pengakuan dari masyarakat. Kedua, secara turun temurun pengelolaan konflik mereka selesaikan dengan asas musyawarah untuk mencari sepakat. Bentuk pengelolaan konflik Hp2S secara "musyawarah mufakat" kebanyakan didominasi oleh laki-laki sebagai orang yang ditokohkan (tetuha) dalam setiap kelompok pemilik Saka. Ketiga, upaya yang dapat dilakukan oleh pemerintah yaitu membentuk ketentuan aturan hukum baru atau adanya rekonstruksi terhadap dasardasar normatif, atau setidaknya peraturan tentang perlindungan nilai-nilai Hp2S ke dalam bekerjanya sistem hukum nasional.
\end{abstract}

Kata kunci: Nelayan saka, sistem hukum nasional 


\section{Pendahuluan}

Penelitian Hukum Masyarakat Nelayan Saka (selanjutnya disebut HMNS) khususnya studi tentang hukum penguasaan, pemilikan, dan konflik ${ }^{2}$ atas keberadaan sejumlah Saka (selanjutnya untuk hukum penguasaan Saka dan hukum pemilikan Saka disebut Hp2S) dilakukan penulis di Desa ${ }^{3}$ Tumbang Nusa Kabupaten Pulang Pisau Kalimantan Tengah.

Keberadaan hukum dituntut untuk merespon segala problematika dan berbagai persilangan kepentingan masyarakat. Hukum sebagai alat rekayasa sosial (social engineering by law) harus berdasarkan pada aspirasi (sebagai perbandingan di Jepang ada istilah "kokoro" $)^{4}$ masyarakat yang hidup beranak-pinak, sarat budaya, dan adat-istiadat ${ }^{5}$. Untuk mencapai tujuan tersebut, diperlukan kepastian hukum, sehingga terpenuhinya kebutuhan dasar kesejahteraan, kemakmuran dan keadilan. Hal ini dilakukan agar hukum tidak berada di ruang hampa. Ruang hampa dimaksud adalah kekosongan peran negara terhadap suatu proses hukum maupun peristiwa hukum yang senyatanya hidup berakar-pinak di masyarakat. HMNS.

Senyatanya, walaupun dari segi legalitas dan otoritas hukum yang diproduksi negara lebih kuat dari pada Hp2S, namun baik legal behavior maupun legal action-nya masih hidup dan fungsional. "Kehampaan hukum" juga bisa dilihat fakta lain, yaitu ketika mandulnya Keppres No. 39 Tahun 1980 tentang

${ }^{1}$ Saka adalah nama anak sungai bermuara ke sungai besar dan atau ke danau, obyek penelitian ini adalah hukum penguasaan dan pemilikan anak-anak sungai Kahayan di Tumbang Nusa Kabupaten Pulang Pisau Kalimantan Tengah (di antaranya ada Saka Paloh, Saka Tambok, Saka Tirus, dan Saka Timin terdapat sedikitnya 157 unit Saka tersebar di Tumbang Nusa dan 32 unit di antaranya mempunyai nama khusus).

2 Terjadinya konflik internal (internal conflict) bagian dari struktur Sum Conflict Hp2S pada HMNS adalah bermula dari kondisi kemajemukan struktur keluarga tergabung dalam kelompok pemilikan Saka sebagai peninggalan pendahulu mereka turun-temurun. Dalam tulisan ini dominan dipakai adalah istilah 'konflik'. Lihat Sabian Utsman, Anatomi Konflike dan Solidaritas Masyarakat Nelayan, Pustaka Pelajar, 2007, hlm.16. Lihat juga Hasan dalam disertasinya, Penyelesaian Sengketa Hukum Berdasarkan Adat Badamai pada Masyarakat Banjar dalam Kerangka Sistem Hukum Nasional, Yogyakarta: PPs FH UII, (2007), hlm.47.

${ }^{3}$ Tulisan Desa (diseragamkan penggunaan sebutan masyarakat terasing kepada masyarakat adat dan legislasi merombak struktur yang asli pemerintahan berbasis masyarakat asli di berbagai persekutuan menjadi "Pemerintahan Desa" melalui UU No: 5 Tahun 1979 tentang Desa) dan Kampung dalam bahasan ini digunakan secara bergiliran mengingat masih seringnya masyarakat setempat menyebut Desa Tumbang Nusa dengan sebutan Kampung Tumbang Nusa atau Perkampungan Tumbang Nusa.

${ }^{4}$ Istilah "kokoro" adalah berarti hati-nurani, yaitu cara-cara berhukum di Jepang, walau bangsanya sudah modern, namun tetap mempertahankan kokoro. Hal tersebut dinyatakan oleh Lafcadio Hearn (1972) dalam Satjipto Rahardjo, Mendudukan Undang-Undang Dasar (Suatu Pembahasan dari Optik. Ilmu Hukum), Semarang; diterbitkan Badan Penerbit Universitas Diponegoro, (2007), hlm.15.

${ }^{5}$ Walau bahasan ini bukanlah secara khusus tentang penelitian hukum adat, tetapi lebih kepada hukum yang hidup di masyarakat nelayan Tumbang Nusa Kalimantan Tengah tentang Hp2S. 
Perizinan Jaring Trwals yang mengakibatkan berkobarnya konflik nelayan lokal dengan nelayan luar daerah. ${ }^{6}$

Pada konteks pembahasan penelitian ini, adanya fakta hukum yang cukup dan fenomenal, sebuah realitas genuine, yaitu penguasaan maupun pemilikan secara kekeluargaan turun-temurun atas sungai-sungai kecil di pinggiran sungai besar (disebut Saka) sebagai wilayah tangkapan nelayan tradisional di pedalaman Kalimantan, khususnya di Tumbang Nusa Kabupaten Pulang Pisau Kalimantan Tengah. Temuan ini menjadi persoalan yang menarik bagi kajian hukum di tanah air, karena di tengah perkembangan globalisasi ilmu hukum dan hukum, ternyata $\mathrm{HMNS}^{7}$ masih hidup dan fungsional dengan segala kearifan, keaslian dan keterbatasnnya sekaligus yang hidup sejak sebelum kemerdekaan Republik Indonesia sampai sekarang.

Daerah Tumbang Nusa termasuk daerah low income earners umumnya tidak mengetahui peraturan perundang-undangan khususnya terkait dengan ketentuan hukum sejumlah Saka, kecuali pengaturan dari Kepala Desa setempat. Misalnya, apabila orang lain selain pemilik Saka yang berkeinginan me' iwak (mau mencari ikan), mereka harus ada izin dari pemilik Saka dengan beberapa ketentuan antara lain “tidak menggunakan racun atau potas, tidak menggunakan alat setrum. Selain itu, menjaga jangan sampai terjadi perkelahian di area Saka tersebut" dan kalau terjadi pelanggaran dari ketentuan mereka, maka diproses secara kekeluargaan antara mereka yang samasama mendapatkan hak milik dari pendahulunya terhadap sejumlah Saka tersebut. Kalau tidak mampu lagi menanganinya, baru diproses kepada kerapatan desa ${ }^{8}$ yang dipimpin langsung oleh kepala desa ${ }^{9}$ untuk menangani kasus tersebut. Konflik atas keberadaan Saka hanyalah pada stadium satu dan belum pernah sampai dibawa ke Kepala Desa apalagi sampai ke lembaga pengadilan pemerintah. Mereka berdamai dengan kearifan hukum kelompok keluarga mereka masing-masing.

${ }^{6}$ Sabian Utsman, Anatomi Konflik ..., Op.Cit., hlm.153-154. Dinyatakan bahwa tidak kurang dari 28 buah Kapal Trawl dari luar daerah bahkan sebagian berasal dari luar negeri menjadi korbannya.

${ }^{7}$ MHNS, dikatakan hukum masyarakat nelayan Saka karena dimana ada masyarakat di situ pasti ada hukum, khususnya masyarakat nelayan yang memanfaatkan keberadaan Saka di Tumbang Nusa, terdapat hukum penguasaan dan hukum pemilikan Saka (Hp2S). Fakta Hp2S sesuai dengan pernyataan Bushar Muhammad dalam bukunya, AsasAsas Hukum Adat (Suatu Pengantar), Jakarta, PT. Pradnya Paramita, hlm. 41,42.

${ }^{8}$ Kerapatan Desa adalah suatu pertemuan atau rapat besar yang diselenggarakan oleh tingkat desa yang dipimpin tokoh masyarakat desa setempat, antara lain untuk mendamaikan perselisihan atau konflik yang ada di desa tersebut setelah tidak mampu didamaikan pada tingkat keluarga atau kelompok di bawahnya, khusus Hp2S biasanya hanya didamaikan di dalam kelompok keluarga pemilik Saka saja.

${ }^{9}$ Sesuai budaya hukum setempat, maka kepala desa sekaligus juga adalah tokoh yang berwibawa sebagai Tetuha Kampung (tokoh masyarakat tertinggi khususnya di desa Tumbang Nusa Kalimantan Tengah). 
Khususnya struktur konflik atas keberadaan hukum terkait penguasaan dan pemilikan Saka (Hp2S) bisa saja terjadi, adalah Zero-Sum Conflict, Non Zero-Sum Conflict, dan Sum Conflict. Dalam hal konflik Hp2S, secara khusus yang terjadi atas keberadaan Saka di Tumbang Nusa adalah lebih kepada konflik internal yang termasuk bagian dari Sum Conflict.

Hukum yang hidup di masyarakat Tumbang Nusa khususnya Hp2S, akan lebih berwibawa kalau di proses secara long march yaitu sejak kebutuhan dan keinginan perorangan, menjadi keinginan golongan, selanjutnya menjadi wacana kebijakan politik, ditingkatkan menjadi permasalahan yang pokok pemerintah, pada akhirnya menjadi agenda penting dalam pembuatan peraturan perundang-undangan, maka diabstraksikanlah ke dalam norma-norma yang lebih tinggi, paling tidak berwujud lahirnya Peraturan Daerah atau Ketetapan Desa terkait sehingga representatif mengatur tentang Hp2S.

Sebagai fokus terpenting bahasan ini adalah studi tentang penguasaan, pemilikan, serta konflik (konflik internal keluarga) atas keberadaan Saka pada nelayan setempat. Hal ini dimaksudkan untuk mengungkap bagaimana kearifan hukum sebagai daya yang timbul dari kekuatan Hp2S (kekuatan dimaksud adalah setidaknya dari sebelum kemerdekaan RI sampai sekarang Hp2S tetap teratur dan fungsional) pada HMNS untuk menjaga tetap tegaknya supremasi hukum yang hidup di masyarakat di Tumbang Nusa, kemudian diakui dan ditransformasikan serta fungsional menjadi bagian dari proses bekerjanya sistem hukum nasional.

\section{Rumusan Masalah}

Adapun berdasarkan dari latar belakang masalah di atas, maka yang menjadi rumusan masalah adalah sebagai berikut. Pertama, bagaimana sosok masyarakat nelayan Saka memahami konsep penguasaan Saka, dan pemilikan Saka yang terkonstruksi (socially constructed) secara turun-temurun sebagai sistem hukum yang hidup di masyarakat nelayan tradisional di Tumbang Nusa Kabupaten Pulang Pisau Kalimantan Tengah? Kedua, bagaimana pengelolaan konflik (How to Manage Conflict) yang dilakukan masyarakat nelayan Saka, ketika mereka menangani kasus-kasus pelanggaran hukum atas penguasaan Saka dan pemilikan Saka di dalam keluarga nelayan setempat? Ketiga, upaya-upaya apakah yang dapat dilakukan agar norma- 
norma hukum masyarakat nelayan Saka mendapatkan pengakuan dalam proses pembangunan sistem hukum baik di tingkat lokal maupun nasional?

\section{Tujuan Penelitian}

Berdasarkan pada permasalahan penelitian, penelitian ini bertujuan untuk mengetahui gambaran yang sesungguhnya tentang: pertama, sosok masyarakat nelayan Saka dalam memahami konsep penguasaan Saka, dan pemilikan Saka yang terkonstruksi (socially constructed) secara turun-temurun sebagai sistem hukum yang hidup di masyarakat nelayan tradisional di Tumbang Nusa Kabupaten Pulang Pisau Kalimantan Tengah. Kedua, pengelolaan konflik (How to Manage Conflict) yang dilakukan masyarakat nelayan Saka, ketika mereka menangani kasus-kasus pelanggaran hukum atas penguasaan Saka dan pemilikan Saka di dalam keluarga nelayan setempat. Ketiga, upaya-upaya yang sudah dilakukan agar norma-norma hukum masyarakat nelayan Saka mendapatkan pengakuan dalam proses pembangunan sistem hukum baik di tingkat lokal maupun nasional.

\section{Metode Penelitian}

Penelitian hukum (legal research) ini adalah menggunakan tipe kajian sosiologi hukum dengan perspektif emik. Karena cara-cara berhukum dengan memberlakukan hukum yang hidup di masyarakat nelayan Saka merupakan tindakan sosial, namun hanya penampakan dari luar tentang apa mereka pahami dan tafsirkan. Untuk mencari makna perilaku dan tindakan berhukumnya, yaitu mengkaji "law as it is in (human) actions" karena berangkat dari hukum adalah manifestasi makna-makna simbolik interaksi masyarakat, oleh karena itu dianalisis secara kualitatif. ${ }^{10}$ Fakta hukum (Hp2S) diperoleh dari 30 orang informan dan 10 orang untuk kepentingan triangulasi, di samping diperoleh dengan studi observasi dan dokumenter.

${ }^{10}$ Lihat Bernard Arief Sidharta, Refleksi tentang Struktur Ilmu Hukum, Mandar Maju, Bandung, 1999, hlm.159. bandingkan juga dengan pemikiran Satjipto Rahardjo, dalam bukunya Ilmu Hukum, PT. Citra Aditya Bakti, Bandung, 2006. hlm.6 menyatakan bahwa ... bagi seseorang yang memahami hukum sebagai alat untuk mengatur masyarakat, maka pilihannya akan jatuh pada penggunaan metode sosiologis. Dan usaha ini mengkaitkan hukum untuk mencapai tujuan-tujuan serta memenuhi kebutuhan-kebutuhan konkrit dalam masyarakat. 


\section{Hasil Penelitian dan Pembahasan}

\section{Konsep Penguasaan Saka}

Masyarakat nelayan tradisional yang memanfaatkan Saka sebagai tempat pencarian ikan di perkampungan Tumbang Nusa belum bisa membedakan antara penguasaan dan pemilikan Saka. Hal itu diketahui, sebagaimana yang terungkap dari beberapa informan ketika penulis menggali perbedaannya di saat penggalian data berlangsung.

Berangkat dari pemikiran sebagaimana kerangka teori, bahwa konsepsi penguasaan Saka adalah modal terpenting bagi nelayan untuk memasuki kebersamaan bahkan pertemanan dalam komunitas nelayan Saka. Tanpa kepastian penguasaan Saka, maka tidak bisa mengembangkan pertemanan dengan baik, bahkan tidak bisa menjaga ketahanan dalam keberlangsungan pekerjaan pokok sebagai nelayan yang bergantung atas keberadaan Saka. Hal ini sangat beralasan, karena memiliki Saka ternyata belumlah tentu atau tidak secara otomatis menguasainya, sebagaimana beberapa informan (antara lain; Ulak, Edy, Amin, dan yang lainnya) yang menyatakan "bahwa penguasaan dan pemilikan atas keberadaan Saka bukanlah secara otomatis memiliki Saka sama dengan menguasainya". Di antara sejumlah Saka belum tentu semua pemiliknya juga menguasainya, ada yang pada saat tertentu semua masyarakat berkuasa untuk mencari ikan di dalam Saka misalkan saja pada musim air bah atau musim banjir, maka semua orang berkuasa dan punya hak untuk mencari ikan di Saka mana saja di Tumbang Nusa.

Penguasaan Saka tersebut, tidaklah terikat hanya berkutat pada kepastian, kemanfaatan, dan keadilan belaka, namun bahkan komitmen dan moralitas wajib dipertimbangkan. Hal ini perlu dikembalikan pada hakekat berhukum adalah membangun sebuah keteraturan, walau tak jarang membangun keteraturan kadang justru semakin jauh dengan keteraturan, kalau dikatakan "melakukan dan atau tidak melakukan adalah hukum", maka diamnya seseorang atau tidak melakukan sesuatu bukanlah terlepas dari hukum.

\section{Konsep Pemilikan Saka}

John Locke mendefinisikan asal mula konsep pemilikan, bahwa pemilikan itu dimulai kalau orang sudah mixing labour di dalam suatu barang. Orang atau 
kelompok orang mengklaim misalkan saja unit Saka sebagai milik suatu kelompok keluarga, kalau sudah melakukan mixing labour, yaitu mencampurkan kerja dengan unit Saka, maka asal mula pemilikan Saka dimulai.

Pemilikan Saka salah satu jaminan basic incame (dalam pemenuhan pendapatan dasar setiap keluarga nelayan Saka). Hal itu menjadi hak alamiah setiap keluarga nelayan terhadap kekayaan alam yang menjadi miliknya serta menjadi kewajiban negara untuk mengatur dan memproteksi, sehingga dengan kuasa negara memanfaatkan hukum sebagai alat untuk ketertiban, maka dari situlah seharusnya dimulai suatu proses keadilan bagi sosial nelayan Saka.

Sejalan dengan perkembangan ilmu pengetahuan tentang hukum pemilikan, fungsi sosial pemilikan bukan saja meluas akan tetapi pemilikan juga penggunaannya untuk menyampaikan ide-ide politik dan sosial. Pemilikan menjadi lambang dari kemenangan atau motivasi pemilikan unit Saka serta politik dan menjadi pendekatan untuk melakukan dan atau tidak melakukan apa saja (indefinite, unrestricted, unlimited) dengan memiliki Saka tersebut. Ada perkembangan dari persoalan individualitas menjurus ke konsep lebih bersifat sosial. Sebagaimana pemikiran Rahardjo dalam hal " pemilikan Saka menjadi lambang kemenangan atau dominasi pemikiran sosial", kenyataan Hp2S adalah realistis, sehingga kepemilikan sejumlah Saka merupakan simbul-simbul kemenangan dalam proses melawan kekerasan nomor satu di dunia, yaitu kemiskinan yang mengkristal melilitmelingkar bagai spiral (spiral kekerasan dan atau spiral kemiskinan) ${ }^{11}$ pada masyarakat marginal Tumbang Nusa Kalimantan Tengah.

Memaknai lambang kemenangan dalam konteks Hp2S adalah ironis. Kejelasan status hukum pemilikan Saka menurut hukum yang hidup pada masyarakat setempat merupakan jaminan kekuatan perekonomian (food security) yang bersangkutan menurut pandangan dan dasar pemikiran mereka (dalam lokal mereka), namun setelah dibandingkan kemajuan dengan perekonomian daerah lain, maka masyarakat nelayan Tumbang Nusa secara keseluruhan adalah dalam keadaan miskin atau berpenghasilan rendah (low income earners). Kemiskinan ini secara

\footnotetext{
${ }^{11}$ Lihat tulisan Dom Helder Camara "Spiral of Violence" dalam Lambang Trijono, Wacana, Jurnal Imu Sosial Transformatif , Edisi 9 Tahun III 2002. hlm. 128, 129, dinyatakan bahwa kekerasan yang disebabkan oleh ketidakadilan..., dalam praktiknya, telah menggelimpang dalam angka-angka yang jenuh, amis, dan membuat kita muntah. Bagi Dom Helder, ketidakadilan adalah "kemiskinan"; itulah kekerasan paling dasar; itulah kekerasan nomor satu. Situasi inilah yang menjerusmuskan manusia ke dalam lubang sub-human - sebuah kubangan yang tak beda dengan kehidupan kerbau atau sapi. ... situasi ini pula pada gilirannya menyumbang atas tergelembungnya tensi pembangkangan ... yang meluas di basis massa ... yang umumnya digerakan oleh anak-anak muda
} 
keseluruhan bisa diukur pendapatan setiap kepala keluarga dalam setiap harinya hanya berpenghasilan dari kerja nelayan (ma'iwak) sebesar antara Rp. 35.000,- (tiga puluh lima ribu rupiah) sampai dengan Rp. 50.000,- (lima puluh ribu rupiah). Di daerah Tumbang Nusa tidak ada penerangan listrik, akses jalan tidak bisa dilewati kendaraan beroda empat (mobil), tata perumahan penduduk masih perlu pembenahan sehingga layak huni.

Perbedaan mendasar dari konsep penguasaan Saka, bahwa pemilikan Saka mempunyai status hukum yang lebih terang, jelas, dan pasti tidak hanya secara kasat mata seseorang terlihat memiliki Saka (tidak hanya bersifat faktual). Ada sejumlah hak yang tidak dipunyai kalau hanya sekadar menguasai.

Dari sejumlah Saka yang dimiliki nelayan secara turun temurun tidak kurang 157 unit Saka, semuanya dimiliki dengan sistem pemilikan keluarga serumpun, yaitu pemilikan dengan cara dari sejumlah Saka dalam satuan pemilikan oleh satu keluarga serumpun, sesama keluarga. Baik tertulis maupun tidak tertulis, dengan pengakuan masyarakat, ada keterangan secara tertulis oleh Kepala Desa yang sekaligus tokoh masyarakat di Tumbang Nusa ${ }^{12}$. Untuk jelasnya proses pemilikan Saka digambarkan berikut:

Sungai-sungai kecil/anak-anak sungai (Saka) masih belum dimiliki penduduk setempat di tengah hutan

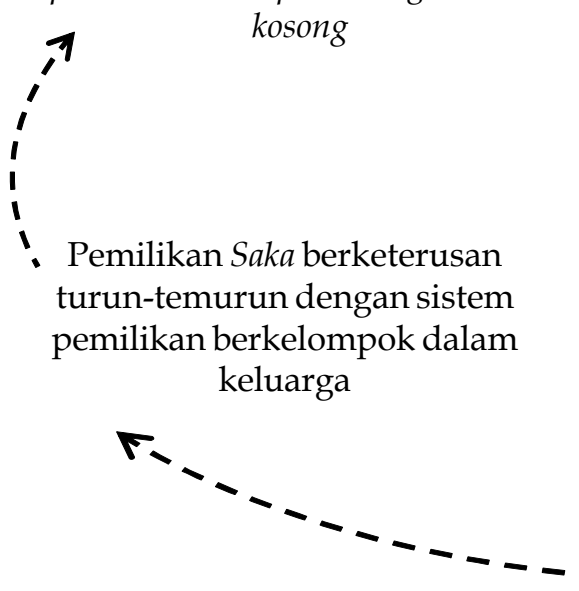

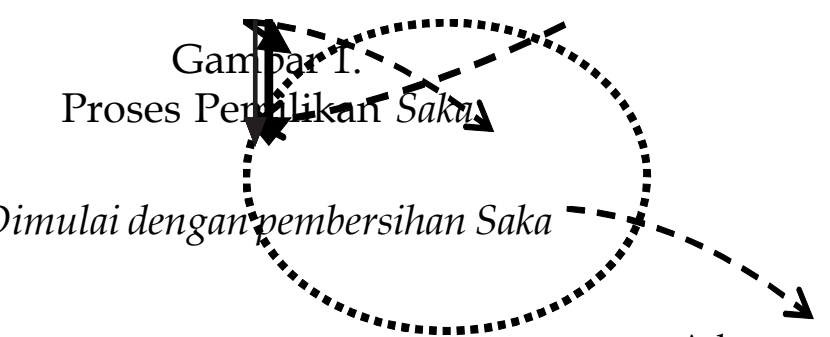

Adanya pengakuan pemilik Saka oleh yang

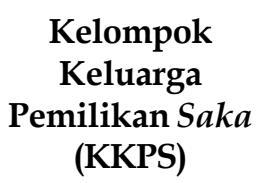
membersihkannya

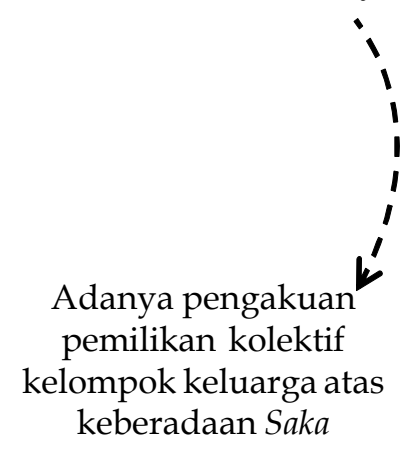

Adanya inisiatif pembuatan bukti tertulis atas kepemilikan Saka

${ }^{12}$ Tokoh masyarakat setempat biasa juga disebut "Tetuha Kampung” yang berarti orang yang dianggap bijaksana dan mampu sebagai pengayom di masyarakat Tumbang Nusa. 


\section{Pengelolaan Konflik atas Tindakan Hp2S}

Terjadinya konflik atas Hp2S di Tumbang Nusa pada saat sekarang memang belum mencapai tingkat yang sifatnya kekerasan. Yang terjadi hanya persoalan biasa sebagaimana karakteristik masyarakat pedesaan pada umumnya, yaitu terjadi konflik sehari-hari. Ade Saptomo menyatakan:

Dalam kehidupan sosial sehari-hari, masyarakat satu dengan yang lain tidak lepas dari persoalan-persoalan perselisihan, baik perselisihan berbentuk keluhan, konflik, maupun sengketa, yang diakibatkan oleh serangkaian interaksi sosial antara anggota masyarakat itu sendiri.

...terhadap masyarakat sangat sederhana, seperti masyarakat pedesaan umumnya, ...menunjukkan bahwa dalam hubungan sosial antara orang satu dengan yang lain jarang sekali ada perselisihan. Meskipun terjadi..., penyelesaianpun sederhana, seperti mengusir, menjauhi, sindiran, dan menghindar. Penyelesaian sengketa dalam masyarakat sederhana demikian ini tidak serta-merta dilakukan secara formal dan melibatkan aturan-aturan tertulis. ${ }^{13}$

Budaya hukum Pancasila, yang sudah ada sejak sebelum kemerdekaan Republik Indonesia, khususnya pengelolaan konflik mengutamakan musyawarah untuk mencapai mufakat (konsensus) selalu menjadi acuan bagi masyarakat nelayan Saka. Adi Sulistiyono menyatakan:

Beberapa penelitian beberapa pakar, pada dasarnya budaya untuk konsiliasi atau musyawarah merupakan nilai masyarakat yang meluas di Indonesia mempunyai budaya penyelesaian sengketa secara damai, misalnya masyarakat Jawa, Bali..., Sulawesi Selatan..., Sumatra Barat, Sumatra Selatan, Lampung, Lombok, Irian Jaya..., dan masyarakat Toraja... . ${ }^{14}$

Dalam pengelolaan konflik pelanggaran Hp2S pada HMNS, hal itu tak terlepas dari substansi dan prosedur hukum, walaupun nampak sangat sederhana bahkan tidak tertulis (idealnya hukum itu dibentuk harus sederhana, mudah dipahami, dan tidak rumit), karena kebanyakan hukum itu diperuntukkan kepada orangorang yang bukan ahli logika, terlebih dalam konteks masyarakat nelayan Saka. Jawahir Thontowi, menyatakan:

...nilai-nilai hukum substantif sebagai seperangkat aturan, dalam bentuk tertulis dan tidak tertulis, yang terwujud sebagai aturan (kewajiban), sebagai keputusankeputusan yang memberi hak kepada orang-orang atau subyek hukum lain

${ }^{13}$ Ade Saptomo Guru Besar Universitas Andalas Padang Sumatra Barat, dalam bukunya Hukum dan Kearifan Lokal (Revitalisasi Hukum Adat Nusantara), Jakarta, PT. Grasindo, 2010, hlm. 95-96.

${ }^{14}$ Baca Adi Sulistiyono Guru Besar Ilmu Hukum Universitas Sebelas Maret Surakarta, dalam bukunya Mengembangkan Paradigma NON-LITIG ASI di Indonesia, Surakarta, diterbitkan oleh Lembaga Pengembangan Pendidikan (LPP) UNS dan UPT Penerbitan dan Pencetakan UNS (UNS Press), (2007), hlm. 31. 
(otorisasi), dan sebagai sanksi.... Sementara itu, hukum sebagai prosedur bisa dilihat sebagai struktur strategi penyelesaian konflik di mana orang atau lembaga hukum yang berwenang melaksanakan hukum tersebut untuk tujuan penyelesaian konflik dan, khususnya, untuk membangun kembali ketentraman desa. ${ }^{15}$

Keberadaan fakta orgasme peristiwa hukum, dan situasi lingkungan sosial berbagai kepentingannya, melahirkan perbedaan dan pertentangan di antara masyarakat nelayan Saka. Menurut Gamble dalam Hamidi: “Konflik merupakan bentrokan sikap-sikap, pendapat-pendapat, perilaku-perilaku, tujuan-tujuan dan kebutuhan-kebutuhan yang bertentangan" ... termasuk juga "perbedaan asumsi, keyakinan dan nilai". ${ }^{16}$

Deutch dalam Bergger, dalam Hamidi ${ }^{17}$, menyatakan bahwa konflik itu akan muncul apabila ada beberapa kepentingan atau aktivitas dalam kehidupan yang saling bertentangan. Bertentangan dimaksud, adalah apabila tindakan tersebut bersifat mencegah, menghalangi, mencampuri, menyakiti, atau membuat tindakan atau aktifitas orang lain menjadi tidak dan atau kurang berarti ataupun kurang efektif. Berdasarkan sumbernya, konflik itu paling tidak mempunyai lima sumber penyebab, sebagaimana dikatakan (Nyi dalam Rakhmat) berikut: (1) kompetisi; satu pihak berupaya meraih sesuatu, dengan mengorbankan pihak lain, (2) dominasi; satu pihak berusaha mengatur yang lain sehingga merasa haknya dibatasi dan dilanggar, (3) kegagalan; menyalahkan pihak tertentu bila terjadi kegagalan pencapaian tujuan, (4) provokasi; satu pihak sering menyinggung perasaan pihak yang lain, (5) perbedaan nilai; terdapat patokan yang berbeda dalam menetapkan benar salahnya suatu masalah. ${ }^{18}$

Konflik yang terjadi di Tumbang Nusa termasuk konflik keluarga dan tertutup. Hal ini terlihat dari beberapa pernyataan tokoh-tokoh nelayan yang juga sebagai tokoh pemerintahan desa antara lain dikatakan Gumerhat S Liwin (Kades Tumbang Nusa), Edy (Ketua RT. II), Adi (Ketua BPD), dan Herman (Kepala Urusan Pemerintahan Desa). Semua kasus pelanggaran hukum tentang Hp2S adalah sesama keluarga, adapun sebagai penyebabnya sehingga berakibat konflik atas tindakan hukum di antara mereka, antara lain: 1) saling berebut sesama keluarga dalam menentukan tempat " $m e^{\prime}$ iwak" sehingga timbul kecemburuan antar mereka; 2) bagi

\footnotetext{
${ }^{15}$ Jawahir Thontowi dalam bukunya Hukum, Kekerasan, dan Kearifan Lokal (Penyelesaian Sengketa di Sulawesi Selatan), Pustaka Fahima, Yogyakarta, 2007, hlm. XXXVIII.

${ }^{16}$ Hamidi, dalam laporan penelitiannya tentang Faktor-Faktoryang Berpengarub terhadap Perilaku Beragama, Tesis, Bandung, Universitas Padjadjaran Bandung, 1995, hlm.25.

${ }^{17}$ Hamidi, Ibid.

${ }^{18}$ Hamidi, Ibid.
} 
mereka yang mendapat peninggalan Saka lebih dari satu dan sudah disepakati bersama di mana untuk ditempati oleh siapa, kadang secara diam-diam terjadi penyerobotan (me'iwak di luar tempatnya); 3) di antara mereka menggunakan peralatan yang dilarang oleh kesepakatan mereka sendiri, seperti: meracun, menuba (akar tuba), menyetrum(aliran listrik), dan meledakan(bahan peledak) penulis sebut menggunakan 4M di area Saka.

Pengelolaan konflik dengan asas musyawarah mufakat akibat pelanggaran Hp2S ditangani dengan kesepakatan mereka dan biasanya menghasilkan perdamaian. Kenyataan itu lebih kepada dimensi waktu dan kearifan budaya hukum lokal setempat.

Penanganan konflik atas tindakan Hp2S yang dilakukan di komunitas nelayan dalam setiap kasus hukum yang menyangkut penguasaan dan pemilikan Saka, senyatanya penanganan tersebut tidak pernah sampai menghadirkan aparat pemerintah di luar desa tersebut, bahkan kepala desa pun belum perlu mengintervensi. Perdamaian itulah sesuai prinsip hukum Pancasila, yang menghargai budaya hukum sebagai kekuatan untuk mempertahankan Hp2S dalam ruang perdamaian kelompok keluarga pemilikan Saka. Untuk menegakkan keadilan, akan lebih berwibawa kalau diabstraksikan dalam wujud peraturan perundangundangan atau ketentuan hukum lainnya. Setidaknya perlindungan terhadap Hp2S melalui Ketetapan Kepala Desa pada Peraturan Pemerintahan Desa Tumbang Nusa Kalimantan Tengah, diproses memperhatikan substansi dan prosedur Hp2S yang hidup di masyarakat setempat, kemudian menjadi bagian dari bekerjanya dalam sistem hukum nasional.

\section{Upaya Pengakuan Hukum Nasional atas Hukum Penguasaan dan Pemilikan Saka}

Sistem hukum nasional yang berawal sejak kemerdekaan RI menjamin atas keberadaan Hp2S. Sepanjang sejarah, Indonesia pernah dijajah beberapa Negara antara lain Belanda, Inggris, dan Jepang. Walaupun negara jajahan menanamkan sistem hukumnya di wilayah jajahannya termasuk di Indonesia, namun masyarakat Indonesia masih mempunyai tata nilai dan hukumnya seperti Hp2S yang hidup sejak jauh sebelum kemerdekaan RI, dan tetap terjamin setelah kemerdekaan. Secara khusus perlu ditransformasikan nilai-nilai Hp2S ke dalam peraturan perundangundangan. Pengaturan tersebut, setidaknya peraturan perlindungan Hp2S, dan kalau memungkinkan ketentuan yang berisi pengaturan penguasaan dan pemilikan Saka, 
sebagaimana juga pengaturan Kedamangan dalam Peraturan Daerah Provinsi Kalimantan Tengah Nomor. 16 Tahun 2008 (Perda No. 16 Tahun 2008) dengan semangat restorative justice mempunyai ekspektasi (expectation) memperjelas dan memberdayakan karakteristik dan identitas pembangunan hukum nasional yang Pancasilais untuk kesejahteraan rakyat.

Dengan kejelasan posisi sistem Hp2S di Tumbang Nusa Kalimantan Tengah, maka cukup landasan atau asas yang kuat untuk mentransformasi nilai-nilai Hp2S kedalam sistem hukum nasional sepanjang memenuhi syarat-sayarat sebagai pelaksanaan dari hukum pancasila, sebagai berikut: 1. Hp2S tidak boleh bertentangan atau bertolak belakang dengan kepentingan hukum nasional yang berprinsip membangun NKRI; 2. Hp2S tidak boleh bertentangan dengan ketentuan peraturan perundang-undangan berlaku sebagai dasar pengaturan rakyat Indonesia dalam bernegara; 3. Hp2S harus bersih dari sifat-sifat feodalisme, kapitalisme, dan pelanggaran Hak Asasi Manusia; 4. Hp2S tidak boleh bertentangan dengan nilainilai agama yang dianut masyarakat setempat.

Demikian halnya yang terjadi dualisme hukum ketika mengizinkan Hp2S tumbuh dan berkembang sebelum adanya Hp2S produk negara, yaitu sistem hukum produk negara yang lebih maju dan sisitem Hp2S yang masih tradisional. Adanya wacana langkah pembentukan $\mathrm{Hp} 2 \mathrm{~S}$ oleh negara dengan mentransformasikan nilainilai yang hidup di masyarakat adalah salah satu langkah mengakhiri "dualisme" sistem hukum dimaksud. Walaupun lahirnya Hp2S 1900 dan istilah hukum adat (adatrecht) pada 1929, serta hukum nasional Indonesia pada 1945, namun semua sistem hukum di dalam Negara Kesatuan Republik Indonesia wajib tunduk pada sistem hukum nasional.

\section{Konsep Transformasi Hp2S dalam Sistem Hukum Nasional}

Pengaturan penguasaan dan pemilikan sejumlah Saka oleh masyarakat nelayan Tumbang Nusa Kalimantan Tengah dengan mengandalkan tokoh sentral keluarga dalam satuan kelompok pemilikan Saka. Kadang dalam satuan pemilikan terdapat beberapa Saka, yang berada di bawah kewenangan tokoh atau tetuha masyarakat yang sekaligus juga sebagai Kepala Desa Tumbang Nusa.

Keberadaan Saka, di samping dari informasi sejumlah informan dan juga adanya bukti keterangan tertulis dalam bentuk surat pemilikan Saka dan salinan tertulis dikenal dengan sebutan "Perkararing" yang dikeluarkan Kepala Desa Tumbang 
Nusa. Informasi Hp2S secara tertulis antara lain bisa dilihat pada surat pemilikan Saka atas nama Liwin (ayah dari nelayan bernama Gumerhat. S. Liwin) yang dikeluarkan pada tanggal 15 Juli 1949, ditulis dengan tangan dan dikeluarkan dengan nomor urut ke 114, bagian isi surat tersebut berisi: ... saya kepala kampung Tumbang Nusa Laga Mantar memberi keterangan bahwa Sungai Bamban (Saka Bamban) di sebelah kanan mudik Selat Nusa Sungai tersebut \pm 1,500 km. Tempat Liwan Kerdja berusaha ikan Liwan ada mempunyai anak 3 orang yaitu 1. Selamat, 2 Saprah, 3 Dulin. ... ${ }^{19}$

Selain keluarga Liwin (ayah dari Gumerhat. S. Liwin berusia 41 tahun) yang mempunyai Surat pemilikan Saka, juga ada keluarga besar Dengok (berusia 54 tahun) yang bagian isi surat pemilikannya secara sederhna dan dalam bahasa yang mudah difahami bagi masyarakat Tumbang Nusa khususnya. Surat pemilikan tersebut secara lengkap sebagai petunjuk, bahwa Hp2S ini sudah ada sejak 1900-an silam dan masih hidup serta fungsional sampai sekarang.

Bagian isi surat pemilikan Saka yang dipunyai oleh keluarga Dengok dengan suratnya yang berjudul "Perkeraring Sungai Tambok" menggunakan mesin ketik, yang dikeluarkan tanggal 1 Juli 1973. Isinya bahwa Sungai Tambok (yang biasa sehari-harinya disebut mereka "Saka Tambok") sudah dimiliki oleh seorang yang bernama Laga bin Mantar sejak 1900 dan diteruskan kepemilikannya kepada empat orang anaknya. Dengan dasar surat tersebutlah seluruh warga nelayan khususnya di perkampungan Tumbang Nusa yang kebanyakan tidak mempunyai surat kepemilikan dan hanya mengandalkan dari pengakuan masyarakat setempat yang dipegang teguh sampai sekarang. Senyatanya rata-rata mereka yang tergantung kepada keberadaan Saka setempat sangatlah menghormati bukti pemilikan tersebut dengan tidak mengabaikan pemilikan yang tidak mempunyai surat.

\section{Upaya Pemerintah}

Hukum hanyalah salah satu dari sejumlah bagian yang bisa sebagai alat yang berfungsi untuk merubah dan atau merekayasa masyarakat (Social Engineering by Law). Sejumlah data yang berhasil dihimpun kaitannya dengan upaya yang

${ }^{19}$ Data tersebut diperoleh dari hasil wawancara dan pengamatan kepada beberapa tokoh atau tetuha masyarakat nelayan dan termasuk Kepala Desa Tumbang Nusa yang juga sebagai pemilik surat keterangan syah kepemilikan Saka tersebut yang diperolehnya secara turun-temurun. Walaupun ada bagian surat sudah dimakan rayap, namun cukuplah memberi sebagian petunjuk bahwa senyatanya ada hukum pemilikan Saka yang masih hidup di daerah setempat. (pengambilan data tersebut terakhir dalam bulan September 2009) 
dilakukan pemerintah agar segenap warga negara Indonesia mendapatkan keadilan sosial serta perlindungan hukum, khususnya terhadap aktivitas yang dilakukan atas keberadaan pengaturan tentang penguasaan dan pemilikan sejumlah Saka di Tumbang Nusa. Keberadaan aturan hukum dan atau peraturan perundangundangan yang transformatif, penting artinya, karena mempunyai fungsi atas kesejahteraan demi martabat suatu bangsa yang tercermin dari kedamaian dan ketenteraman hidup dan kehidupan warganya.

Untuk mencapai maksud di atas, kata "kewajiban" bagi negara untuk melakukan upaya serius adalah suatu konsekuensi bagi negara yang menjunjung tinggi nilai-nilai demokratis yang sering dikatakan bahwa negara Indonesia adalah negara hukum. Demikian juga tanggungjawab negara terhadap Hp2S pada HMNS di Tumbang Nusa khususnya, yang senyatanya hidup dan fungsional mengatur penguasaan dan pemilikan sejumlah Saka sejak sebelum kemerdekaan yang masih hidup dan fungsional.

Upaya pemerintah hendaknya bukan saja mengabstraksikan hukum Saka (Hp2S) ke dalam dasar-dasar normatif, baik sebagai pengaturan maupun perlindungannya. Namun, tetap bertanggungjawab sesuai kompetensinya untuk melestarikan hakhak tradisional Hp2S.

Upaya masyarakat Tumbang Nusa untuk menjadikan hukum yang hidup dan mempunyai dukungan yang kuat dari pemerintah, senyatanya tokoh kosmopolitan yang bernama Gumerhat S. Liwin (Kepala Desa Tumbang Nusa) berpendapat, bahwa masyarakat Tumbang Nusa mempunyai harapan yang kuat (hanya punya ide dan keinginan, tidak punya kompetensi untuk itu) karena tidak punya kewenangan untuk menjadikan hukum mereka (Hp2S) sebagai bagian dari peraturan hukum negara. Mereka sebagai masyarakat hanyalah berperan aktif dalam setiap pemilihan umum yang dilaksanakan pada waktu tertentu untuk menyampaikan kepentingan mereka khususnya kepentingan hak-hak hukum tradisional tentang penguasaan dan pemilikan Saka.

Sosok Hp2S dibuat, bukan saja sebagai jawaban kepentingan hukum sesuai dengan karakteristik bangsa Indonesia, dibuat bukan saja sebagai jawaban kepentingan hukum untuk ke kemajuan globalisasi sesuai nilai-nilai hukum Pancasila tetap terjaga, yang "cerdas dan berbudaya". Namun, untuk mewujudkan cita-cita, atas keinginan masyarakat nelayan Saka Tumbang Nusa, agar memiliki Hp2S sebagai bagian dari bekerjanya sistem hukum nasional, maka langkah transformatif agar nilai-nilai Hp2S menjadi bagian yang tak terpisahkan dalam 
strukturasi hukum nasional adalah menjadi tepat. Dengan demikian, tidak mustahil di suatu saat, maka terwujudlah sebagai bagian dari "Modern Society and Responsif Law", yaitu sosok hukum yang beridentitas nasional Indonesia, hidup, komprehensif, fungsional, dan progresif.

\section{Penutup}

Dari uraian di atas, dapat disimpulkan sebagai berikut. Pertama, sejarah penguasaan dan pemilikan Saka merupakan salah satu bukti adanya hukum yang kuat, bahwa Saka terpelihara secara terus-menerus. Penguasaan Saka adalah bersifat sementara sebelum mempunyai ketetapan menjadi pemilik. Pemilikan Saka mempunyai status hukum yang lebih terang, jelas, dan pasti tidak hanya bersifat faktual, dan mempunyai sejumlah hak, tanggungjawab, perintah, larangan, dan sanksi. Proses pemilikan Saka, mereka mulai dari menemukan Saka yang belum dimiliki, setelah dibersihkan, diakui mereka sebagai miliknya, dan kemudian mendapat pengakuan masyarakat.

Kedua, dalam pengelolaan konflik, secara turun temurun mereka melakukan dengan asas musyawarah untuk mencari sepakat sehingga konflik tidak menjadi lebih besar, dan selalu berakhir pada level pertama saja, serta terjadi perdamaian sebagaimana keadaan sebelum konflik. Bentuk pengelolaan konflik Hp2S secara "musyawarah mufakat" kebanyakan didominasi oleh laki-laki sebagai orang yang ditokohkan (tetuha) dalam setiap kelompok pemilik Saka. Pengelolaan konflik Hp2S adalah berlandaskan nilai luhur Pancasila sebagai sumber dari segala sumber hukum di Indonesia.

Ketiga, upaya-upaya untuk mendapat pengakuan hukum nasional atas keberadaan $\mathrm{Hp} 2 S$ yang dilakukan pemerintah yaitu pembentukan ketentuan aturan hukum baru atau adanya rekonstruksi terhadap dasar-dasar normatif, atau setidaknya peraturan tentang perlindungan nilai-nilai Hp2S ke dalam bekerjanya sistem hukum nasional.

Sesuai problematika dan bahasan serta kesimpulan atas keberadaan Hp2S pada HMNS di Tumbang Nusa Kalimantan Tengah, maka penulis merekomendasikan sebagai berikut. Pertama, langkah mentransformasikan nilai-nilai Hp2S ke dalam sistem hukum nasional, diharapkan setidaknya berbentuk lahirnya peraturan untuk melindungi realitas genuine Hp2S atau kalau memungkinkan bentuk aturan yang mengatur Hp2S. Kedua, langkah transformasi yang substansial adalah menanamkan 
nilai-nilai “Hukum Pancasila”. Nilai fundamental Hukum Pancasila sebagai hukum yang ideal berkaedah atau bernilai dasar; “Berketuhanan, Berkemanusiaan, Berpersatuan, Berkerakyatan, dan Berkeadilan", sehingga seutuhnya terwujud karakteristik Hp2S sebagai kekayaan hukum lokal yang masih hidup, arif, dan fungsional berlatar ke-Indonesiaan.

\section{Daftar Pustaka}

Arief Sidharta, Bernard, Refleksi tentang Struktur Ilmu Hukum, Mandar Maju, Bandung, 1999.

Hamidi, dalam laporan penelitiannya tentang Faktor-Faktor yang Berpengaruh terhadap Perilaku Beragama, (Tesis), Bandung, Universitas Padjadjaran Bandung, 1995.

Hasan, Ahmadi, Penyelesaian Sengketa Hukum Berdasarkan Adat Badamai pada Masyarakat Banjar dalam Kerangka Sistem Hukum Nasional, Disertasi, Program Pascasarjana FH UII, Yogyakarta, 2007.

Muhammad, Bushar, Asas-Asas Hukum Adat (Suatu Pengantar), PT. Pradnya Paramita, Jakarta, 2002.

Rahardjo, Satjipto, Ilmu Hukum, PT. Citra Aditya Bakti, Bandung, 2006. , Mendudukan Undang-Undang Dasar (Suatu Pembahasan dari Optik Ilmu Hukum), diterbitkan Badan Penerbit Universitas Diponegoro, Semarang, 2007.

Saptomo, Ade, Hukum dan Kearifan Lokal (Revitalisasi Hukum Adat Nusantara), PT. Grasindo, Jakarta, 2010.

Sulistiyono, Adi, Mengembangkan Paradigma Non-Litigasi di Indonesia, Sebelas Maret University Press, Surakarta, 2007.

Thontowi, Jawahir, Hukum, Kekerasan E Kearifan Lokal (Penyelesaian Sengketa di Sulawesi Selatan, Pustaka FAHIMA, Yogyakarta, 2007.

Trijono, Lambang, Wacana, Jurnal Ilmu Sosial Transformatif, Edisi 9 Tahun III 2002.

Utsman, Sabian, Anatomi Konflik dan Solidaritas Masyarakat Nelayan, Pustaka Pelajar, Yogyakarta, 2007. 